\title{
Weak Regulations and Application of Mining Laws that Are Not Profitable for Countries or Locations of Community Mining
}

\author{
Diana Ria Winanti Napitupulu \\ Doctoral Program of Law Science \\ Faculty of Law, Universitas Brawijaya \\ Malang, Indonesia \\ napitupulu.dina@gmail.com
}

\author{
Bambang Eryanto Hermawan \\ Doctoral Program of Law Science \\ Faculty of Law, Universitas Brawijaya \\ Malang, Indonesia \\ b_e_hermawan@yahoo.co.id
}

\begin{abstract}
In mineral and coal mining businesses have an important role in providing significant added value to national economic growth and sustainable regional development, whose implementation is still constrained authority between central and local government, licensing, processing and refining, protection of affected communities, data and information mining supervision, and sanctions, so that the implementation of mineral and coal mining is less effective and has not been able to provide optimal added value. Where in the regulation concerning mineral and coal mining which is currently regulated in Law Number 4 Year 2009 regarding Mineral and Coal Mining still need to be darified First, the issue of obligation to increase the added value of minerals; Second, adjustment of work contracts (COW) and coal mining concession works (PKP2B); Third, the adjustment with Law no. 23 of 2014 on Regional Government; Fourth, related to the decision of the Constitutional Court which covers the determination of mining areas. In order for the new Minerals and Coal Act functions to regulate fiscal and non-fiscal incentives for companies to develop smelter scrubbers and improvement of mining land (reclamation), due to the occurrence of Degradation on ex-mining land include changes in soil physical and chemical properties, both the flora, fauna and soil microorganisms, the formation of canopy (cover area) which causes a fast dry land and the occurrence of soil microorganism changes, so the environment grows less pleasant. In other words, that degraded land conditions have low fertility rates and poor soil structures.
\end{abstract}

Keywords- weak regulation and application of law

\section{INT RODUCTION}

Article 33 paragraph (3) of the 1945 constitution mandates that the earth, water and the wealth contained therein belong to the state and are used to the greatest extent possible for the prosperity of the people. It sounds like this article gives the state the freedom to maximize the potential that exists within the Indonesian state. The utilization of this potential should be oriented towards the interests of the country and of course the prosperity of the people.

On paper, this law looks very partial to the interests of the people. However, the implementation is far from the fire. Since the promulgation of Law No.32 of 2004 concerning regional autonomy, the soundness of the 1945 constitution, especially article 33 has increasingly disappeared
The promulgation of Law No. 32 of 2004 basically aims to end the centralization regime where the center has full authority to regulate the region. The centralized regime has weaknesses where the government does not holistically accommodate the interests of the community. That is because the distance from the center to the regions is so difficult to see the reality of people's lives. In addition, this Act aims to develop equitable development that has been difficult for centralized regimes for years to develop. The enactment of the Law brings hope that the government will be closer to the people.

In the Act, the first and second level regional governments are given full authority to develop the region. Policies no longer have to wait for orders from the center. However, the region, in this case the regional head has the flexibility to build his area. Of course, the hope is to build the area in accordance with the orders of the law and to be oriented to the interests of the people.

The authority of the regional government is seen in many aspects. One of them is the authority to grant mining business licenses (IUP) previously owned by the central government. The authority to grant IPU is often problematic. In the mass media; print and electronic, news about the head of the region who is having problems because of haphazardly issuing IUP is often presented. Until 2013, the Ministry of Energy and Mineral Resources noted that the IUP which was declared clear and clean was only 5502 out of 10,809 IUPs. This means that the IUP has a problem or not clear and clean of 5,307 IUPs. So, almost half of the IUP is problematic. However, it should be noted, there are still many mining activities in the regions that the ESDM Ministry failed to monitor. Therefore, the heavy duty is carried out by the Ministry of Energy and Mineral Resources to curb the problematic IPU-IUP.

\section{DISCUSSION ISSUES}

\section{A. Platform for Mining Mining Objects}

Mining legal objects are targets in the investigation or study of mining law. The object is divided into two types, namely the material object and the formal object. The material object is the material (material) that was targeted in its investigation. Mining legal material objects are human and quarry material. While formal objects are certain points of view on material objects. So, the formal object of mining 
law is to reconcile the relationship between the state and quarries and the relationship between the state and a pers on or legal entity in the use of excavated materials.

The position of the state is as the owner of the mineral material regulating the allocation and use of minerals for the prosperity of the community so that the state controls the excavation material. The aim of the control by the state is that national wealth is utilized for the greatest prosperity of all the people of Indonesia. Thus, both individuals, communities and business people, even if they have the right to a piece of land on the surface, do not have the right to control or possess excavated materials beneath it, in accordance with the principle of horizontal separation in land law.

The control by the state is carried out by the government as the mining authority holder. The power of mining is the authority granted by the state to the government to carry out exploration and exploitation activities, both for strategic excavation materials, commodities and class $\mathrm{C}$.

Meanwhile, the scope of mining law studies includes general mining and oil and gas mining. General mining is classified into five categories, namely:

1. Radioactive mineral mining;

2. Metal mineral mining;

3. Non-metal mineral mining;

4. Solid coal, peat and bitumen mining; and

5. Geothermal mining.

In early 2009, the government is sued Law No. 4 of 2009 concerning Mineral and Coal Mining. After the enactment of this Act, it also ends the licensing regime in the form of a contract / agreement. Furthermore, all permits must use the Mining Business Permit (IUP) pattern. Therefore, the Directorate General of Mineral and Coal carried out activities to re-register permits in the mining sector issued by the Regional Government throughout Indonesia. This data collection is carried out by conducting an inventory, verification and classification. This data collection (reconciliation) is very important as a basis for the future National Mining policy direction as well as a comprehensive national IUP database.

With the arrangement of permits being carried out, this is a government effort in order to regulate mining permits in Indonesia. IUP that has been well arranged will have a positive impact on the implementation of policies and state revenues. Among them are as follows: IUP can be used as a basis for determining Mining Areas; coordination material with other agencies in determining spatial planning so that it can find overlap between regions; overlap between sectors and overlap between IUP holders; optimization of non-tax state revenues (fixed fees, royalties, mining sales) from IUP; opportunities for increasing mineral and coal added value; knowing the national production of minerals and coal; as a basis for determining the fulfillment of domestic needs (DMO); increase the contribution of the national mining services business; increasing human resource needs; and can also be used for environmental management

Law No. 4 of 2009 defines as well as classifies IUP in several forms. Here's the explanation:

1. Mining Business Permit, hereinafter referred to as IUP, is a permit to carry out mining business.
2. Exploration IUP is a business license given to undertake stages of general investigation, exploration, and feasibility studies

3. Production Operation IUP is a business license granted after completion of the Exploration IUP to carry out the stages of production operations.

4. People's Mining Permit, hereinafter referred to as IPR, is a permit to carry out mining business in a community mining area with limited area and investment.

5. Special Mining Business Permit, hereinafter referred to as IUPK, is a permit to carry out mining business in the area of a specialmining business license.

6. Exploration IUPK is a business license given to carry out the stages of general investigation, exploration and feasibility study activities in the area of a special mining business license.

7. Production Operation IUPK is a business license granted after completion of the Exp loration IUPK to carry out the stages of production operations in the area of a special mining business license.

\section{B. Mining Business Permit (IUP)}

"Presence of Law No. 4 of 2009 concerning Mineral and Coal (Minerba Law) is based on the intention to improve the management of mineral and coal mining in Indonesia. One of the essence of improvements contained in the Minerba Law is to rearrange overlapping permits ".

One of the obstacles to implementing Law No. 4 of 2009 concerning Minerba is that the Law is considered to be too general. Meanwhile, in the case of mineral mining there are several specific conditions, which cannot be accommodated in the general law. For example, it used to have a rule that if you want to mine you must have an exploration mining permit (IUP) and must have at least 5,000 square meters. In fact, these requirements are not relevant in various regions. Bangka Belitung for example, the area of 5,000 square meters is no longer there. If referring to the rule, the new IUP cannot be opened automatically in the area.

The regulation concerning the 5,000-square meter IUP area is to limit permits. Based on data from the Minis try of Energy and Mineral Resources, there are already more than 10,000 permits recorded. Conditions need to be taken seriously. This means that if you do not tighten permit require ments, the number will continue to increase to 20,000 permits later, because of the ease of giving permission.

However, another problem facing is the lack of supervision aspects of licensing. It is conceivable that there are regions that have issued hundreds of permits but apparently, they do not have supervisory personnel. The process of granting permission is supervised. Every region should have a mine inspector. Even if the area already has a mine inspector, the amount is still relatively insufficient compared to the number of permits being submitted. The weak supervision of the granting of this permit is a problem.

Then the second, contract adjustment. If we talk legally the contract adjustment should be done within a period of one year in accordance with the Minerba Act. By law, this actually creates contradictions too, because on the one hand the government respects the principle of pacta sun servanda: the contract must be respected as a Law. But on the other 
hand, the government also has an obligation to amend the contract to be fairer.

We also want the effort to renegotiate Contracts of Work to be understood by the public that this is actually also for the benefit of the community. This does not mean that the government does not respect the contract, but keep in mind that the current condition also differs between the past and the present.

Why is it fairer? We take the example of Freeport. Are we willing PT Freeport Indonesia to pay only 1 percent of royalties, while the current regulation is 3.75 percent? Local entrepreneurs must pay 3.75 percent, while PT Freeport Indonesia only pays 1 percent. In terms of justice this is certainly very disturbing. Therefore, the government continues to seek renegotiation of existing contracts before the new rules apply.

Also based on Article 170 of Law Number 4 of 2009, it is stated that the Contract of Work holders are required to carry out mineral refining within 5 years of Law No. 4 of 2009, meaning that since 2014 Freeport as a Contract Holder can no longer export copper concentrate, and Article 170 of Law Number 4 of 2009 also says that if a Contract of Work that has not been habitual, the validity period still wants to export the concentrate to be changed to a Special Mining Business License (IUPK) and if the Contract of Work expires or is extended, it must be changed to a Mining Business License Special (IUPK), but with protracted negotiations seen Freeport rejects the IUPK as a concentrate export permit given by the government and retains its rights as in the Contract of Work

The government is currently making efforts to restructure minerba management. One of them is by tightening the mining permit issue. This means that the government will be more selective in providing IUPs. Now the government has made signs, even in the Minerba Law there is a criminal provision if the is suer of permits to issue an IUP is not in accordance with its authority, it can be subject to criminal sanctions

Now the government's priority is to make arrangements and tighten the existing IUP so that in the future mining industry activities will continue to run and investment will not be constrained.

\section{Implications of Weakness in the Minerba Act}

" A lawsuit due to dissatisfaction with a regulation can be submitted by anyone. Against this Mierba Act, it remains open that there may be parties who disagree with this Law because they feel aggrieved.

However, there must also be parties who share the Law on the Law on the akat because they feel they benefit. Agreeing and disagreeing about the legislation product is something that is normal, especially in a democratic nature like today.

Those who feel that they are not in agreement with the Minerba Law can take a lawsuit against a regulation as a constitutional law corridor. So, all the implications which according to some parties are negative implications please be submitted to be tested in accordance with the applicable law. The government respects it while respecting all forms of legal action taken. Even against the Supreme Court's ruling which according to the government cannot be issued, the government still respects and carries out the decision. Even though the govemment made the regulation, but when a state institution according to the Basic Law has the authority to is sue the decision, the government will respect it.

\section{Implementing Rules for the Minerba Act}

The implementing regulations for the Minerba Act continue to be complemented. The government has prepared around 20 ministerial regulations to implement the four PPs that carry out the mandate of the Minerba Law. It can be said that almost all implementation rules have been discussed. But the problem is that there is a mining area (WP) that has not come out. If the WP has not yet come out, then the issuance of IUP is practically impossible. Therefore, after WP comes out next the government will is sue the rules of the game. Until now, the implementation rules of the Minerba Act are actually already in the finalization stage. The last step that is being awaited is waiting for WP.

For the Government Regulation (PP), to date there are four PPs which are derived from the Minerba Act. There is even one revised PP, PP No. 23 of 2010 concerning the Implementation of Mineral and Coal Mining Business Activities was revised to PP No. 24 of 2012.

The revised PP is expected to be more operational. In general, it has been seen that there is compliance from the local government and the community to follow it. But there are also parties who have not complied with it.

Regarding the environment, we currently have a special PP about that, namely PP No. 78 of 2010 concerning Reclamation and Post-Mining. This PP is evidence that the Minerba Law strongly emphasizes environmental sustainability in managing the mine.

For aspects of environmental crime, we already have Law No. 32 of 2009 concerning the Environ ment. Violations of environmental aspects, in any context, refer to the Environmental Law. Like-wise, with mineral and coal mining, if there are parties who commit environmental crimes, they will be charged under the Environmental Law, not by the Minerba Law.

Especially for PP 78 of 2010, what is regulated is the obligation of the company to reclaim after carrying out mining production activities. So, before a company gets an IUP, especially an exploration IUP, they must take care of the environmental permit first and proceed with the EIA. So that in principle every mining company must have complete environmental documents to obtain an IUP of production operations.

If the company does not have complete environmental documents, then of course it can be subject to criminal as stipulated in the Minerba Act. In the context of reclamation, basically companies are required not only to be able to mine, but also to recover, can restore damaged land.

There is also a reclamation guarantee, when getting an IUP the company must pay a guarantee in the form of a deposit. If the company does not reclaim or recover damage to the land from activities.

In practice so far, attention to environmental aspects has become an obstacle. Many mining sites after mining are not considered. The promise of reclamation only became solace. The mining community is a victim. For example, in Freeport, 
the Amugme and Kumoro communities were victims of mining crimes. They must be evacuated to other areas. They must leave their hometown which is their mother

\section{CONCLUSION}

1. Licensing: it needs supervision both in licensing and extension, taking into account economic growth and empowering communities around mining;

2. Supervision of the management of guarantee funds for reclams and post-mining in a transparent manner.

\section{SUGGESTIONS}

1. Contract of Work: need to add clauses of amendments that can be implemented in accordance with the times and justice so that there is a government veto as an authority holder so that there is a chance to renegotiate the contract, and the extension of the Contract of Work is a conversion to a Special Mining Business License (IUPK);

2. Environ mental impact analysis: must be carried out not only at the beginning as a licensing requirement but in a manner that can minimize environ mental damage and community protection

\section{REFERENCES}

[1] Adami Chazawi, Criminal Law Lesson Part 1, Jakarta: PT. Raja Grafindo Persada, 2002;

[2] Andi Hamzah, Principles of Criminal Law, Jakarta: P.T Rinaka Cipta, 1994; Oheo K Haris: Legal Aspect of Criminal, 1994;

[3] ___ Principles of Criminal Law, Jakarta: Rineka Cipta, 1991

[4] ___ Indonesian Criminal Procedure Code, Revised Edition, Jakarta: Sinar Grafika, 2006;
[5] Bambang Poernomo, Principles of Criminal Law, Jakarta: Ghalia Indonesia, 1985;

[6] Barda Nawawi Arief, Culmination of Criminal Law Policy, Bandung: PT. Citra Aditya Bhakti, 1996.

[7] ___ Some Aspects of Criminal Law Enforcement and Development Policy, Bandung: Citra Adit ya Bakti, 1 st Print, 1998;

[8] ___ Kapita Selekta Penal Law on Integrated Criminal Justice System, Diponegoro University Publishing Agency, Semarang, 2006;

[9] ___ Cultivation Bureau of Criminal Law Policy (Development of Preparation of New Criminal Code Concept), Jakarta: Kencana, 2008;

[10] _ Development of Indonesian Criminal Law Principles, Library Magister Semarang, 2008;

[11] E Utrecht, Criminal Law 1, University of Indonesia, Jakarta, 1956;

[12] Loebby Loqman, "Development of Legality Principles in Indonesian Penal Code", Paper Presented at Seminar on National Criminal Law Principles Organized By: National Legal Development Board Ministry of Justice and Human Rights, in collaboration with Diponegoro University Faculty of Law, Semarang, Puri Suite Hotel Ciputra, Semarang, 26-27 April 2004. In the explanation of D. Hazewinkel-Suringa, Inleiding tot de studie van het Nederlandse Strafrecht, 1983;

[13] Philipus.M Hadjon, Paul Effendie Lotulung, H.M. Laica.Marzuki, Tatiek.Sri Djatmiati, I Gusti Ngurah Wairocana, Administrative and Good Governance Law, Jakarta: Trisakti University, 2010;M. Young, The Technical Writer's Handbook. Mill Valley, CA: University Science, 1989.

\section{RELATED LAWS AND REGULATIONS IN INDONESIA}

[1] Law Number 11 Year 1967 concerning Mining Basic Regulations (State Gazette Year 1967 Number 22);

[2] Law Number 4 of 2009 concerning Mineral and Coal Mining (St at ute Book of 2009 No. 4);

[3] Government Regulation Number 22 Year 2010 concerning Mining Areas (State Gazette Year 2010 Number 28); 